\title{
Expert in Ancient Russian Culture (to the 100th Birth Anniversary of Professor V.V. Kuskov)
}

Медиевистика на протяжении многих десятилетий является важным направлением научной и преподавательской деятельности на кафедре истории русской литературы филологического факультета МГУ. Курс древнерусской литературы занимает особое место в системе университетского филологического образования: им открывается цикл дисциплин по истории русской литературы. Изучение этого фундаментального предмета в последней трети XX в. было связано с именем заслуженного профессора МГУ, лауреата Ломоносовской премии Первой степени (1988) Владимира Владимировича Кускова (31.07.1920 - 31.07.1999).

Владимир Владимирович родился на Смоленщине в семье служащих. Его дед был священником. Возможно, от него будущему ученому передалась любовь к стародавнему слову, рукописному наследию, мудрости предков. Путь в филологию начался в 1937 г., с поступления в Московский институт истории, философии и литературы имени Н.Г. Чернышевского (МИФЛИ). Как известно, в 30-е гг. ряд гуманитарных факультетов был выведен из состава Московского университета. Институт находился в зеленом районе города - на Ростокинском проезде, позади парка Сокольники. И сегодня в том непримечательном в архитектурном отношении здании продолжаются занятия студентов одного из факультетов Московского лингвистического университета. Станция недавно открывшегося метро в те годы была конечной, и в Ростокино от Сокольнической заставы ходил трамвай.

МИФЛИ славился своими преподавателями. Назовем лишь некоторые имена выдающихся филологов: Л.Е. Пинский, Г.Н. Поспелов, А.М. Селищев, С.И. Соболевский, Д.Н. Ушаков. Древнерусскую литературу читал Н.К. Гудзий, которому суждено было сыграть важную роль в судьбе В.В. Кускова. В сентябре 1938 г. второкурсники-ифлийцы приступили к изучению средневековой литературы. Многих слушателей сразу же увлекла эта дисциплина. В первую очередь это было связано с личностью лектора, к тому времени уже известного медиевиста, ученика академика В.Н. Перетца. Н.К. Гудзий тогда создал новый курс древнерусской литературы, привлекший внимание общественности к книжному наследию средневековой Руси. Особое внимание при отборе памятников уделялось их художе- 
ственности, эстетическим качествам. Так совпало, что именно в это время готовилось к печати первое издание ставшего впоследствии классическим его учебника «История древней русской литературы». Гудзий демонстрировал интересующимся студентам гранки своей книги, выход которой в свет стал знаковым событием, определившим на долгие годы направление вузовского преподавания.

Славу предвоенному МИФЛИ составили многие его воспитанники. В 30-е гг. на разных курсах литературного факультета учились А. Твардовский, Ю. Левитанский, Б. Слуцкий, С. Гудзенко, К. Симонов, П. Коган, С. Наровчатов, Д. Самойлов. Целая плеяда выпускников МИФЛИ стала впоследствии историками русской литературы. Так, на кафедре истории русской литературы филологического факультета МГУ вместе с В.В. Кусковым будут преподавать его однокашники - профессора В.И. Кулешов и П.Г. Пустовойт, курсом младше учился будущий профессор П.А. Орлов.

Со второго курса В.В. Кусков стал специализироваться в области медиевистики, записавшись в семинар Гудзия, который перед войной был деканом литературного факультета. Эти занятия проходили в течение трех лет. Вместе с Кусковым участником семинара был его однокурсник А.Н. Робинсон, также ставший впоследствии видным специалистом в области древнерусской литературы.

Мирные студенческие годы прервала война. Уже в августе 1941 г. выпускник МИФЛИ был призван Сокольническим райвоенкоматом. В год 75-летия Победы особо следует вспомнить о фронтовых заслугах В.В. Кускова. Он участвовал в боях с ноября 1941 г. в качестве рядового красноармейца. Филологические способности и знание немецкого языка пригодились в военные годы. С честью пройдя испытания первых месяцев службы, Кусков стал переводчиком разведотдела 1273 стрелкового полка 287 стрелковой дивизии. Это воинское подразделение сражалось на подступах к Сталинграду, на реке Миус, участвовало в освобождении Донбасса и Крымского полуострова. Ратный труд Владимира Владимировича отмечен рядом наград, в том числе: медалями «За оборону Сталинграда» (1943), «За боевые заслуги» (1943), «За победу над Германией» (1945) и орденами «Отечественной войны» II степени (1944) и «Красной звезды» (1945). Из Красной армии лейтенант Кусков был демобилизован в декабре 1945 г.

Война закончилась. В годы эвакуации в лоно университета вернулся филологический факультет. Еще находясь в армии, осенью 1945 г., Владимир Владимирович решает продолжить образование в аспирантуре. В это время его часть находилась в Венгрии. Он написал письмо на имя декана филологического факультета, в котором интересовался правилами приема в аспирантуру. Ответ пришел быстро. Писал сам профессор Гудзий, который был рад получить известие от своего довоенного студента.

Так в октябре 1946 г. жизнь снова свела этих двух людей, преданных древнерусской литературе. С 1946 по 1949 г. Кусков был аспирантом Николая Каллиниковича. Тема, над которой он работал в аспирантуре, была связана с исследованием литературных особенностей «Степенной книги», выдающегося памятника XVI в. Вспоминая аспирантские годы, Кусков с особой теплотой писал о том внимании и заботе, которыми окружал молодых ученых Гудзий, его семинар по источниковедению (1947/48 гг.), проходивший по средам. Позднее Кусков писал об этом: «Семинар пользовался большой популярностью. На него приходили не только аспиранты кафедры русской литературы МГУ, но и аспиранты ИМЛИ, Академии общественных наук»¹ .

${ }^{1}$ Кусков В.В. На лекциях и в семинаре МИФЛИ // Воспоминания о Николае Каллиниковиче Гудзии. М.: Изд-во МГУ., 1968. С. 61. 
После окончания аспирантуры в 1949 г. Владимир Владимирович уехал работать в Уральский университет имени А.М. Горького (Свердловск). Последующие годы его научной и преподавательской деятельности были связаны с этим вузом, где он заведовал кафедрой русской и зарубежной литературы и читал множество разнообразных курсов. Свою кандидатскую диссертацию ««Степенная книга» как памятник литературы XVI в.» он защитил только в 1952 г., став к тому времени опытным преподавателем. В 1958 г. им была организована Уральская археографическая экспедиция, научные результаты которой были весьма значительными.

Наибольшую известность В.В. Кускову, конечно, принес вузовский учебник «История древнерусской литературы», выросший из курса лекций, много лет читавшихся и изданных сначала в Свердловске (1962), а потом, уже с конца 60-х гг., и в Москве (в МГУ В.В. Кусков вернулся в 1967 г.). С 1966 г. и по настоящее время учебник переиздавался более десятка раз. Книга впитала в себя все лучшее, что отличало учебник его учителя Гудзия. Вместе с тем уже при беглом сопоставлении этих двух книг открывается принципиальное своеобразие учебника Кускова. И дело не только в том, что здесь освещаются проблемы, возникшие в науке за последние годы. По-иному построено само изложение предмета. Если прежде главное внимание уделялось идейной, содержательной стороне памятников, то теперь акцент сделан на художественной специфике древних текстов, их жанровых и стилевых особенностях. Это связано с тем, что сами тексты стали гораздо доступнее для студентов, чем прежде, появились разнообразные их издания. Хрестоматия уже давно перестала быть единственным собранием текстов, входящих в программу. Ценным свойством книги является ее компактность, удобство и доступность для первокурсников.

«История древнерусской литературы» стала главной частью целого комплекса учебной литературы, созданного В.В. Кусковым. Упомянем такие сопутствующие издания, как хрестоматия «Древнерусская литература в исследованиях» (1986) и учебное пособие «История древнерусской литературы» для студентов национальных вузов (1987) - в соавторстве с Н.И. Прокофьевым. В 1994 г. под редакцией Владимира Владимировича вышел словарь-справочник «Литература и культура Древней Руси». Помимо сведений о произведениях средневековой книжности, в справочнике содержится разнообразная информация о важнейших явлениях древнерусской архитектуры и изобразительного искусства, генеалогические таблицы, русский месяцеслов. Словарь, ориентированный на потребности школьников и студентов, помогает разобраться в трудах и концепциях крупнейших ученых.

Кусковым был подготовлен ряд популярных изданий памятников древнерусской литературы, которые в немалой степени способствовали ознакомлению широкой читательской аудитории с сокровищами нашей средневековой книжности. В 1978 г. под редакцией Кускова с его вступительной статьей в издательстве «Московский рабочий» вышла книга «Пламенное слово: Проза и поэзия Древней Руси», куда вошли фрагменты не только важнейших произведений XI-XVII вв., но и наиболее известные былины. Уже после кончины ученого в 2001 г. увидела свет книга «Древнерусские княжеские жития», где читателю предлагались тексты подчас малоизвестных произведений, сопровожденные современными переводами.

В своих работах Кусков уделял внимание рецепции древнерусской литературы писателями XIX в. Ряд статей посвящен традициям древнерусской книжности в творчестве А.С. Пушкина, поэтов-романтиков, Л.Н. Толстого, Ф.М. Достоевского. В отдельных статьях освещались средневековые эстетические представления, 
вопросы взаимодействия литературы и искусства, ретроспективная историческая аналогия, представленная в памятниках XIV-XV вв., система жанров. Некоторые из этих статей были впоследствии переизданы в сборнике «Эстетика идеальной жизни» (2000). Сложной теоретической проблеме системы жанров была посвящена и докторская диссертация «Жанры и стили древнерусской литературы XI первой половины XIII веков», защищенная в 1980 г.

Лекции Кускова мне довелось слушать не однажды. Спокойно-размеренная манера повествования с легким грассированием, лишенная внешней эффектности, неизменно привлекала слушателей. Особенно запомнилось гармоничное сочетание рассмотрения идей и содержания древних произведений и их поэтики. Конечно, автору университетского учебника необходимо избегать дублирования информации в лекциях. Это методически непростая задача. Кусков умел найти в своем рассказе о давних явлениях словесности новые краски и повороты темы. Все это по-своему дополняло и расширяло материал, делало его объемным. Владимир Владимирович был выдающимся лектором, с огромным опытом работы в различной аудитории.

Помимо основного, фундаментального курса семивековой истории древнерусской литературы, профессор Кусков читал и ряд специальных курсов, пользовавшихся неизменным вниманием студентов и аспирантов. Вспоминается один из таких циклов удивительно содержательных занятий, на которых собиралось полтора десятка студентов разных курсов. Было это в середине 70-х гг. На спецкурсе подробнейшим образом рассматривалась система жанров древнерусской литературы. Тогда в поле нашего зрения впервые попали многие духовные тексты, библейские и евангельские мотивы и образы, о чем советской молодежи того времени было известно мало. Перед нами предстала огромная тема - русская Библия в основных моментах своей истории. Особо запомнилось занятие, посвященное разбору Изборника Святослава 1073 г., в том числе так называемой статьи Георгия Хиробоска «Об образех», где объяснялись 27 риторических фигур и тропов. Уже позже я узнал, что именно над проблемой жанров Владимир Владимирович работал тогда при подготовке докторской диссертации. Уже в 90-е гг. особой популярностью не только у студентов филологического факультета, но и у слушателей из ряда других вузов пользовался новаторский по тем временам спецкурс «Православие и культура», заполнявший определенные лакуны познаний молодежи о русской культуре в первые постсоветские годы.

Методика преподавания, манера проведения учебных занятий стали хорошей профессиональной школой для ряда учеников Кускова, приступивших в дальнейшем к самостоятельной преподавательской деятельности. Мне в аспирантские годы довелось прочитать свою первую лекцию, проходя педагогическую практику под руководством Кускова. В 9 поточной аудитории мне была предоставлена возможность провести занятие в рамках общего курса, который тогда читал Владимир Владимирович. Темой стали произведения, отразившие монголо-татарское нашествие, литература трагического XIII в. Преодолевая волнение, я справился со своей задачей, но не рассчитал время и ошибочно отпустил студентов на 15 минут раньше. Переживал по этому поводу и ждал суровой критики от Владимира Владимировича. Однако он даже не упомянул об этой ошибке, дав о общем положительную оценку лекции. Были сделаны лишь некоторые уточнения по существу.

Следует особо упомянуть о том, как постепенно Владимир Владимирович вводил своих учеников в среду московских ученых-древников. Мы, аспиранты, 
приглашались им на доклады в ИМЛИ имени А.М. Горького, где могли участвовать в обсуждении некоторых трудов по истории древнерусской литературы. В те годы Кусков участвовал в подготовке совместно с учеными ИМЛИ пятитомного издания «Ранняя русская драматургия» (1972-1975), а также оказывал помощь в работе над исследованиями «Русская старопечатная литература» (1978-1981). На слушаниях в секторе древнерусской литературы состоялось мое знакомство с такими известными прежде только по публикациям учеными, как А.Н. Робинсон, Н.И. Прокофьев, О.А. Державина, А.С. Елеонская, А.С. Демин, В.П. Гребенюк. На мои научные интересы впоследствии особое влияние оказал А.С. Демин, многие годы объединявший в своем семинарии медиевистов нескольких поколений. Там еженедельно делались доклады, и Владимир Владимирович нередко приходил в ИМЛИ послушать выступления своих учеников, принять участие в обсуждении предложенных материалов.

Предмет, которому посвятил себя Владимир Владимирович, в советское время находился под постоянным контролем властей. Подчас это «внимание» принимало угрожающие формы. Поэтому в профессиональной судьбе Кускова бывали непростые моменты. Впервые с идеологическим давлением он столкнулся еще в аспирантуре: «Помню, как моя тема, связанная с изучением Степенной книги... стала подвергаться ожесточенным нападкам» ${ }^{1}$. Тогда молодого ученого поддержал Н.К. Гудзий. В начале 80-х гг. произошел краткий, но совершенно беспрецедентный по тем временам всплеск государственного атеизма. Тогда Владимир Владимирович напечатал в «Советской России» книгу житий. Это издательство выпускало массовую серию «Сокровища древнерусской литературы», формировавшуюся по жанровому принципу. Книга называлась «Древнерусские предания» и включала тексты известных агиографических произведений. Как составитель, Кусков попал в числе других авторов под пресс огульной критики. В газете «Правда» были напечатаны статьи, «разоблачающие» близорукую издательскую политику, пропаганду религиозных идей. Владимир Владимирович мужественно выстоял в этой непростой ситуации. К счастью, вскоре времена изменились, и массовым тиражом была напечатана знаменитая, но недоступная у нас дотоле книга Г.П. Федотова «Святые Древней Руси».

Сегодня, когда уже несколько месяцев университетские занятия проходят онлайн, вспоминаются неоднократные визиты в дом профессора Кускова. На меня, тогда аспиранта, как и на всех молодых людей, побывавших в гостях, производила впечатление стандартная квартира в пятиэтажном доме в районе Матвеевское: все стены от пола до потолка, включая коридор, были покрыты книгами. Обсуждение различных материалов, статей или глав диссертаций происходило в небольшой комнате, за письменным столом у окна. Часто Владимир Владимирович вставал и быстро снимал с полки нужную книгу, подчас весьма редкую. Это помогало оперативно сверить цитату, найти подтверждение догадке, проверить библиографическую справку. На рубеже 1970-1980-х гг. еще, конечно, не было персональных компьютеров. В случае надобности на столе появлялась портативная пишущая машинка, на которой профессор мог быстро отпечатать необходимый отзыв или характеристику на своего ученика.

После окончания аспирантуры мне много лет довелось работать на кафедре бок о бок с Владимиром Владимировичем, вести за ним практические занятия, вместе принимать зачеты и экзамены. Словом, выполнять обычные преподава-

\footnotetext{
${ }^{1}$ Кусков В.В. На лекциях и в семинаре в МИФЛИ. С.62.
} 
тельские обязанности, ассистируя известному профессору. В общении он всегда был корректно сдержан, иногда даже казался излишне сухим. Лишь изредка в частной беседе становился более эмоциональным, открытым. Неизменно поражала его эрудиция. Он был непревзойденным знатоком древнерусской культуры и истории, с готовностью делился этими знаниями.

Вот один из примеров. Однажды иностранным отделом факультета была организована автобусная экскурсия в Суздаль. Владимир Владимирович любезно согласился выполнить роль консультанта туристической группы. На протяжении всего неблизкого пути преподаватели, некоторые с детьми, аспиранты из разных стран слушали удивительный рассказ об истории, культуре и книжности северо-восточной Руси. Архитектура, судьбы правителей XII в., местные легенды и даже бытовые реалии средневекового города открывались перед его слушателями. Ни один профессиональный экскурсовод не смог бы соперничать с Владимиром Владимировичем в умении заинтересовать людей, далеких от медиевистики. Помню, что в эту поездку профессор взял с собой одного из внуков - мальчика младшего школьного возраста, который тогда, быть может, впервые увидел деда с совершенно неведомой стороны. Выходя из автобуса, со всей детской непосредственностью, ребенок восторженно произнес: «Дедушка, откуда ты все это знаешь?»

Навещая Владимира Владимировича в больнице незадолго до его кончины, я узнал от лежавших вместе с ним в палате, что и на больничной койке по просьбе товарищей по несчастью он рассказывал о древнерусской литературе, писателях XIX в., тем самым поддерживая в людях интерес к жизни, вселяя надежду на скорейшее выздоровление.

В заключение отметим, что за долгие годы преподавательской деятельности на кафедре истории русской литературы Кусков вырастил множество учеников, работающих в ряде вузов страны. Владимир Владимирович считал своим долгом всячески помогать не только своим выпускникам, но и всем молодым коллегам из других городов. Авторитет ученого простирался далеко за пределы страны, ведь он долгое время преподавал за рубежом (США, университет штата Огайо; Финляндия, университет г. Хельсинки). Сегодня воспитанники профессора Кускова продолжают дело изучения и преподавания древнерусской книжности и культуры, а его учебник по-прежнему рекомендован учащимся бакалавриата филологических факультетов.

\section{ЛИТЕРАТУРА О В.В. КУСКОВЕ}

«Слово о полку Игореве» в литературе, искусстве, науке: Краткий энциклопедический словарь. Минск., 1989. С. 135.

Энциклопедия «Слова о полку Игореве»: В 5 т. Т. 3. СПб., 1995, С. 124-126.

Профессора и доктора МГУ имени М.В. Ломоносова. М., 1998. С. 389. C. 61 .

Филологический факультет Московского университета: Очерки истории. М., 2001.

Филологический факультет Московского университета: Энциклопедический словарь. M., 2005. C. 157-158.

Нечаева T.B. Научные труды Владимира Владимировича Кускова // Герменевтика древнерусской литературы: Сб. 7. Ч. 2. М., 1994. С. 478-487.

Гребенюк В.П. Памяти ученого - педагога // Герменевтика древнерусской литературы: Сб. 10. М., 2000. С. 718-719. 
Конявская Е.Л. Владимир Владимирович Кусков - ученый и учитель // Древняя Русь. Вопросы медиевистики. 2000. № 1. С. 105-113.

Хализев B.E. Человек с чертами русского праведника: Владимир Владимирович Кусков // Хализев В.Е. В кругу филологов. Воспоминания и портреты. М., 2011.

Русские литературоведы XX века: биобиблиографический словарь. Т. І: А-Л - . М.; СПб., 2017. С. 430-431.

\section{LITERATURE ABOUT V.V. KUSKOV}

"The Tale of Igor's Campaign" in Literature, Art, Science: A Brief Encyclopedic Dictionary. Minsk. 1989, p. 135.

An Encyclopedia “The Tale of Igor's Campaign": In 5 vols. Vol.3. St. Petersburg. 1995, pp. 124-126.

Professors and Doctors of Lomonosov Moscow State University. Moscow. 1998, p. 389.

Philological Faculty of Moscow University: Essays on History. Moscow. 2001, p. 61.

Philological Faculty of Moscow University: An Encyclopedic Dictionary. Moscow. 2005, pp. 157-158.

Nechaeva T.V. Scientific Works of Vladimir Vladimirovich Kuskov. In: Hermeneutics of Ancient Russian Literature: The collection 7. Part. 2.Moscow. 1994, pp. 478-487.

Grebenyuk V.P. In Memory of the Scientist - Professor. In: Hermeneutics of Ancient Russian Literature: The collection 10. Moscow. 2000, pp 718-719.

Konyavskaya E.L. Vladimir Vladimirovich Kuskov - the Scientist and Professor. Ancient Russia. Questions of Medieval Studies. 2000. No 1, pp. 105-113.

Khalizev V.E. A Man with the Features of a Russian Righteous Man: Vladimir Vladimirovich Kuskov // Khalizev V.E. In the Circle of Philologists. Memories and Portraits. Moscow. 2011.

Russian Literary Critics of the $20^{\text {th }}$ century: A Biobibliographic Dictionary. Vol. I: A-L - . Moscow; St. Petersburg. 2017, pp. 430-431.

Сведения об авторе:

Алексей Аркадьевич Пауткин,

доктор филол. наук

профессор

филологический факультет

МГУ имени М.В. Ломоносова
Alexey A. Pautkin,

Doctor of Philology

Professor

Philological Faculty

Lomonosov Moscow State University

apautkin@yandex.ru 